\title{
The influence of terracettes on the surface hydrology of steep-sloping and subalpine environments: some preliminary findings
}

\author{
P. Greenwood, S. Kuonen, W. Fister, and N. J. Kuhn \\ Physical Geography \& Environmental Change, Department of Environmental Sciences, \\ University of Basel, Basel, Switzerland
}

Correspondence to: P. Greenwood (philip.greenwood@unibas.ch)

Received: 12 July 2014 - Revised: 15 October 2014 - Accepted: 5 November 2014 - Published: 23 February 2015

\begin{abstract}
Alpine and mountain slopes represent important pathways that link high-altitude grazing areas to meadows and rangelands at lower elevations. Given the often acute gradients associated with such environments, they potentially represent highly efficient runoff conveyance routes that facilitate the downslope movement of runoff and associated material during erosion events. Many such slopes host series of small steps, or "terracettes". The juxtaposition of terracettes against the natural downslope flow path of non-complex slopes leads us to hypothesise that they may influence typical hillslope processes by intercepting or capturing surface runoff. Here we report preliminary results and some tentative conclusions from ongoing work to explore this possibility. Google Earth was used to initially identify a ca. $400 \mathrm{~m}^{2}$ well-developed terracette system situated on a west-facing slope with gradients ranging from 25 to $40^{\circ}$ (46 to $84 \%$ ). A digital elevation model (DEM) of the terracettes was constructed using spatial data taken from a relevant section of topographic map. The DEM was then queried using a flow-accumulation algorithm and the results displayed in a geographic information system. The output data provided "proof of concept" that terracettes can capture surface runoff. The generation of empirical data from a series of rainfall/runoff simulations performed on the same section of terracettes supports this finding. Results from both work components indicate that sections of a terracette system may intercept runoff and could act as preferential flow pathways. By contrast, some sections appeared to act as depositional sites. We cautiously predict that these areas could act as retention zones for the temporary storage of runoff-associated substances. Greater understanding of the exact influence of terracettes on surface hydrology in steep-sloping and subalpine environments could benefit the future management of grazing and rangelands in such areas.
\end{abstract}

1

\section{Introduction}

Alpine and mountain slopes represent important sources of fodder for grazing livestock. In addition, they also act as convenient routes with the potential to link high-altitude grazing areas to meadows and rangelands located at lower elevations (Michna et al., 2013; Hoffman et al., 2014). Given the often acute gradients encountered within terrain of this nature (Konz et al., 2012), their presence (theoretically) represents a convenient and potentially highly efficient runoff conveyance route with the capacity to facilitate the rapid and largely unimpeded downslope transfer of surface runoff and associated material during erosion events. Despite this reali- sation, however, many slopes above a certain threshold gradient (Waugh, 1995) host a series of small steps, or "terracettes", that have an appearance analogous to a wide staircase (Rahm, 1962). Whilst much has been written about the origin of terracettes and the processes thought to have led to their formation (e.g. Ødum, 1922; Rahm, 1962; Bell, 1981; Buckhouse and Krueger, 1981; Auzet and Ambroise, 1996; Henck et al., 2010), two lines of thought usually prevail. The first is that the upper layer of soil gradually moves downslope by soil creep (Carson adn Kirkby, 1972; Anderson and Cox, 1978; Waugh, 1995; Heimsath et al., 2002; Anderson and Anderson, 2011). Repeated wetting and drying cycles facilitate the downslope movement, which, combined with grav- 


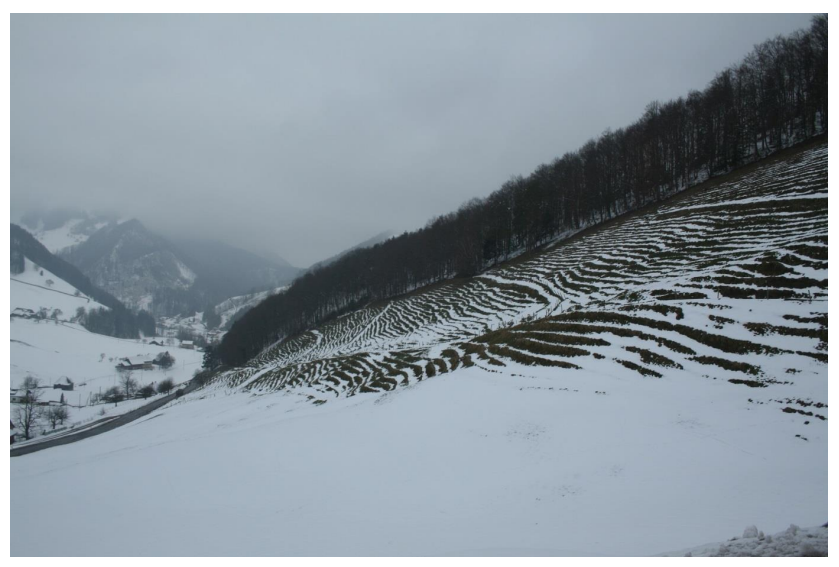

Figure 1. Terracettes are particularly prominent and arguably become most visually striking in wintertime when snow accumulates at the point where the two geomorphic components (i.e. the runner and the riser) meet.

ity, results in the almost uniform series of small steps (Vincent and Clarke, 1980; Auzet and Ambroise, 1996; Bielecki and Mueller, 2008; Heimsath et al., 2002). Whilst terracettes may initially form by a combination of hillslope processes and gravity, many people speculate that they are actually accentuated by the trampling action of livestock, which tend to use them as convenient pathways to gain access to different areas of grazing (Buckhouse and Krueger, 1981; Waugh, 1995).

With regard to their characteristics and appearance, terracettes usually consist of individual steps that are arranged in parallel at more or less equidistant intervals from each other but generally dip at a slight angle across-slope. Despite the fact that terracettes are exclusively developed on a pasture and are hence always covered with relatively dense vegetation, their distinct profile is usually visually most striking in wintertime when, for instance, snow accumulates at the back, where runners (i.e. the flat steps) and risers (i.e. the near-horizontal backslopes) meet, and contrasts against the dark edge of the runners, as can be seen in Fig. 1. In terms of dimensions, runners can range in width from ca. 0.15 to $0.75 \mathrm{~m}$, whereas risers can range in height from a barely perceptible 0.025 to $1.2 \mathrm{~m}$ (Rahm, 1962). If viewed in cross profile, however, pairs of runners and risers are generally asymmetric, with the length and height of each usually being of unequal dimensions, as can clearly be seen in Fig. 2.

With this background information, we hypothesise that terracettes, juxtaposed against the natural downslope flowdirection of often acute slopes, may intercept or impede the natural downslope flow of surface runoff (Kuhn and Zhu, 2008). We do not suggest, however, that individual terracettes form a neatly interconnected system in which runoff is forced to systematically traverse, or "zigzag", its way downslope via a series of conveniently linked flow paths. Instead, we postulate that individual terracettes may sufficiently capture, or

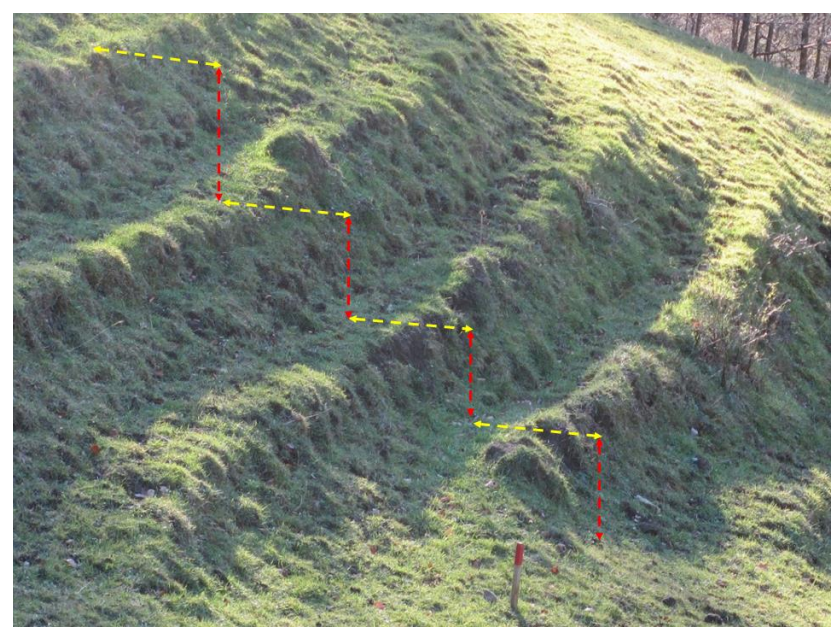

Figure 2. A section of a terracette system showing three individual steps has been overlain with dashed arrows in order to highlight runners. The dimensions of those shown in this example are asymmetric, and the length of risers are considerably longer than the length of runners.

at least impede, the flow of runoff to make it descend slowly or in stages and where, between events, it may even be temporarily stored.

Given the lack of literature on the subject, the hypothesis is largely conceptual-based and is tested using a package of work that firstly involves runoff modelling with GIS and is then followed by a series of field-based rainfall simulations. Both components sought to establish overall "proof of concept" that terracettes have the ability to influence surface hydrology by intercepting, capturing or impeding surface runoff. The first phase was done using digitized threedimensional data. This was then queried using a flow accumulation model and the output displayed in a GIS. The result from this first component of the investigation was then supported by the generation of empirical runoff data sets, which were obtained by conducting a series of simulated rainfall events on bounded sections of a terracette system.

\section{Materials and method}

The investigation to determine whether slope terracettes influence surface hydrology in steeply sloping environments was achieved using a two-phase approach. The first phase involved undertaking a desktop study in which "proof of concept" was established. The aim of this component of the investigation was to conceptually demonstrate the ability of terracettes to capture, and thus influence, surface runoff. After firstly identifying and then "ground-truthing" a well-developed terracette system using Google Earth, threedimensional data were taken from a relevant topographic map and from digital imagery. Aspects from both data sources were then merged to construct a bespoke digital el- 

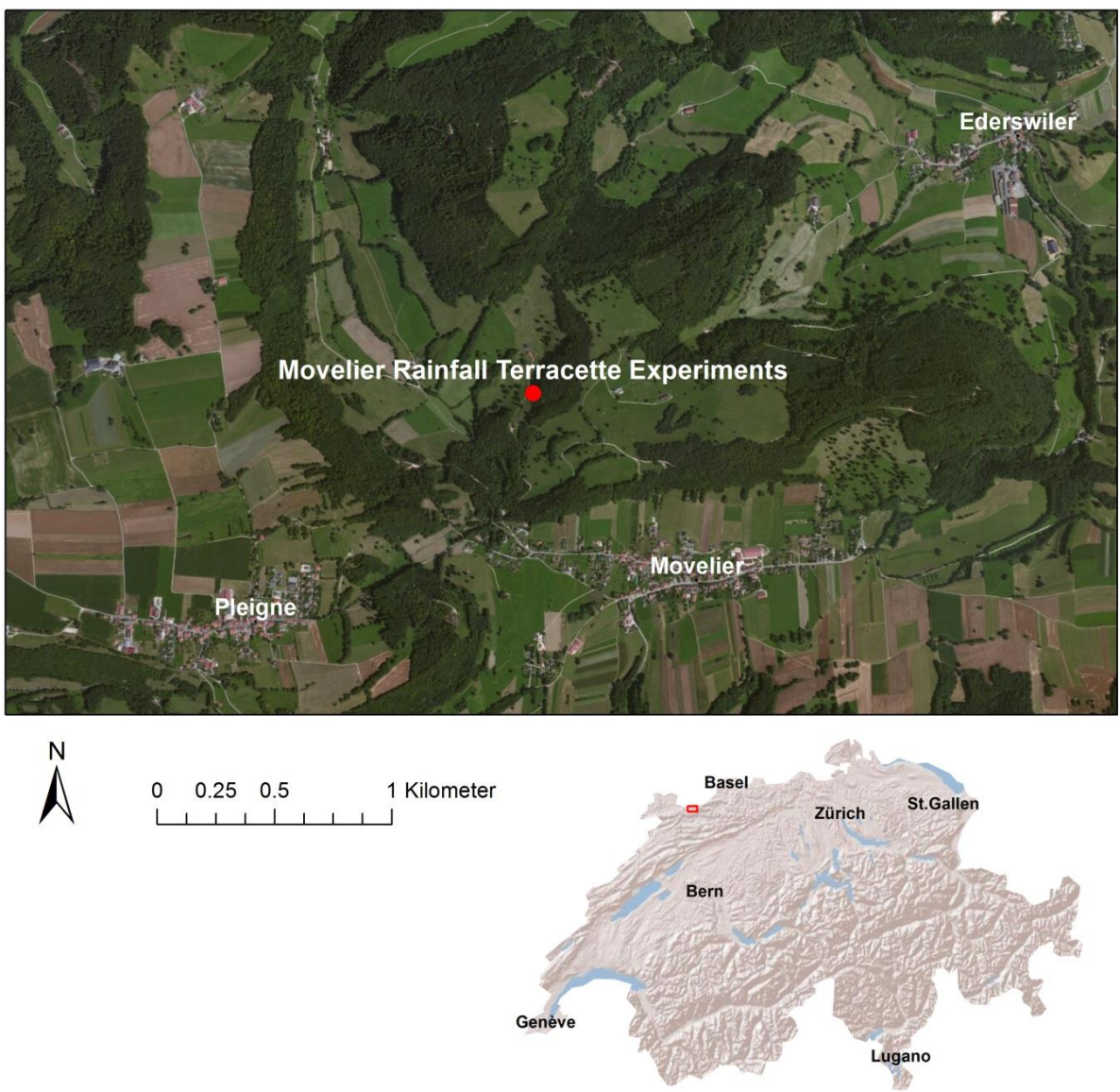

Figure 3. A map showing the location of the study site in northwest Switzerland.

evation model (DEM) of the section of the terracette system under scrutiny. The DEM was then entered into a GIS environment, queried and the resultant data displayed using the visual output of the GIS. After obtaining proof of concept, the second experiment-based phase was implemented. This involved applying simulated rainfall at a known intensity and for a predetermined duration across small (i.e. $\sim 1 \mathrm{~m}^{2}$ ), bounded erosion plots located on selected sections of terracettes in order to assess the relative time during which runoff could be generated. Information from each rainfall simulation is further supplemented with in situ bulk-density and soil-pore data, volumetric moisture content and climate data that include precipitation, air temperature and soil matric potential for the two 5-day periods before each set of rainfall simulations were conducted.

\subsection{The study site}

A ca. $400 \mathrm{~m}^{2}$ section of a suitably well-pronounced terracette system was provisionally identified within the Jura region of northwest Switzerland $\left(47^{\circ} 25^{\prime} 00.58^{\prime \prime} \mathrm{N} ; 7^{\circ} 18^{\prime} 30.06^{\prime \prime} \mathrm{E}\right)$ using Google Earth. The chosen site on which both phases of the investigation focused is situated approximately $10 \mathrm{~km}$ northwest of the town of Delémont (Fig. 3) and was "groundtruthed" in order to confirm that it was sufficient for the needs of the investigation and logistically accessible. The geology of upland areas within the Jura mountain region is composed of Jurassic limestone. Elevations range from 500 to $1300 \mathrm{~m}$ a.s.l. and the elevation of the chosen study site lies approximately $710 \mathrm{~m}$ a.s.l. A general description of the climate of this region is given in Greenwood and Kuhn (2014); in brief, annual precipitation is around $1100 \mathrm{~mm}$ with maximum monthly rainfall at ca. $91 \mathrm{~mm}$, usually falling between the May to September period. Autumn and winter months can receive as much as $80 \%$ of the monthly maximum precipitation (ca. $73 \mathrm{~mm}$ ), but much of this frequently falls as snow. Sub-zero temperatures usually commence from around December onwards and can persist until early March. This means that snowfall frequently accumulates, particularly in shady valley bottoms and on east- and north-facing slopes, where it can persist and remain until mid-spring. Runoff events in the Jura region commonly occur throughout the year (Prasuhn, 1991, 2011; Ogermann et al., 2003; Ledermann et al., 2008), resulting in soil erosion. Although incidences of erosion are usually most prevalent on cultivated hillslopes, such events are commonly initiated by unconcen- 
trated run-on originating from upland pasture (Ogermann et al., 2003).

Despite terracettes reportedly being most prevalent on east- to north-facing slopes (Buckhouse and Krueger, 1981), the terracette system within the selected study area is relatively well-developed and located on a west-facing slope, with gradients ranging from ca. 25 to $40^{\circ}$ (46 to $84 \%$ ). The acute gradients and general nature of the terrain preclude any form of intensive agriculture from taking place, but the site is extensively grazed by cattle from around April to September, with stock densities equivalent to 1 livestock unit (1 unit is one cow) per hectare (G. Broquet, personal communication, 2014). Vegetation on and around the study site consists predominantly of a relatively dense cover of fine-leaved grasses. These are interspersed with a wide variety of higher-order alpine and subalpine flowering plant species, which collectively provide rich, high-quality grazing that is inherent to many infertile calcareous soils that develop on limestone-based hillslopes in the Jura and other regions (Rodwell, 1998). The depth of soil profile at this particular location was estimated at around $15-20 \mathrm{~cm}$ and, in keeping with limestone-based calcareous terrain, $\mathrm{pH}$ was estimated at around 8-8.5. The west-facing location at this particular site means that soil is probably subject to aspect-related physical influences that include regular desiccation, particularly the surface during warmer months (Rorison, 1990). Bare, partially vegetated or recently cultivated soils in this region are also prone to surface crusting, even after relatively light yet prolonged rainfall.

Key physical characteristics of the parent soil were determined, both at the study site and at a relatively flat meadow area located downslope of the study area. Particle size diameter was determined for both sites using a Malvern Mastersizer. Median $\left(D_{50}\right)$ measured 14.6 and $17.2 \mu \mathrm{m}$ for slope and meadow sites respectively. Based on the generally similar 17 , 78 and $5 \%$ proportions of sand, silt and clay respectively, both soils are classified as a silty loam using the textural classification system adopted by Hodgson (1974, in White, 2000).

\subsection{Creating a digital elevation model}

The aim of this component of the investigation was to construct a digital elevation model (DEM) from a suitable area based on topographic information obtained from a 1:25000 map (Landeskarte 1086; Delémont), which focused on a section of Canton Jura in northwest Switzerland. For the construction process, the relevant section of the map was firstly scanned and then imported into a geographic information system (ArcMap 10.0, Environmental Systems Research Institute). From this, three shape files were then created. The first delineated the exact outline of the chosen study area and the second was used to depict contour lines (i.e. isolines) showing areas of similar elevation within the corresponding study area. Both shape files were then digitized from the to- pographic map and saved with the attributed elevation values as a separate, yet corresponding, shape file. Once these stages were completed and all data were successfully digitized, the Topo-to-Raster tool in ArcMap was used to interpolate those individual attributes in order to create a hydrologically correct raster surface DEM based on contour lines, elevation spot-heights and depth contours.

\subsection{Integrating terracette paths on to the digital elevation model}

Due to the fact that small-scale features such as terracette paths cannot be represented in two-dimensional topographic maps, it was necessary to integrate these features into the DEM. This was achieved by identifying terracettes from a combination of aerial and more recent digital photographs of the study sites. Terracettes were then subjected to on-screen digitization in ArcMap by converting them firstly to a shape file and then to a raster file. For simplicity and ease of data manipulation, arbitrary height and width values equivalent to $0.5 \mathrm{~m}$ were attributed to both runners and risers respectively. By merging the raster file depicting the terracettes with the DEM of the raster surface file using the "Raster Calculator" tool in ArcMap, the terracettes, now with nominal height and width dimensions of $0.5 \times 0.5 \mathrm{~m}$, became the prominent object on the DEM surface (Fig. 4).

\subsection{Runoff simulation}

For the runoff simulation, IDIRSI Taiga version 16.05 was used (Clark Laboratories). Firstly, however, it was necessary to convert and export two digital elevation models, one with terracettes and one without terracettes, from ArcGIS raster format to an ASCII raster file format so that it could be read by IDRISI, as this is the GIS software package of preference for the operator when manipulating raster data. In IDRISI, both DEMs were then adjusted using the "PIT REMOVAL" tool, which creates a refined "depressionless" DEM in which individual cells corresponding to depressional areas are artificially raised to the lowest elevation value measured at an arbitrary point around the outer periphery of the nearby depression. This represents an important stage from the perspective of querying subsequent hydrological analyses, as it reduces the amount of "sink" areas where the simulated runoff would tend to accumulate but remain static (Kuhn and Zhu, 2008). Once all of those factors were established, it was necessary to calculate the flow directions. In IDRISI, the "FLOW" tool determines the flow direction of surface runoff by calculating slope gradients between adjacent cells. Flow then logically commences from the direction of the slope registering the most acute gradient. Next, runoff accumulation was calculated using a "RUNOFF' tool. This calculates the accumulation of rainfall units for each pixel, based on the assumption that 1 unit of precipitation uniformly falls on each location within the predefined study area. Those stages were under- 
Digital Elevation Model

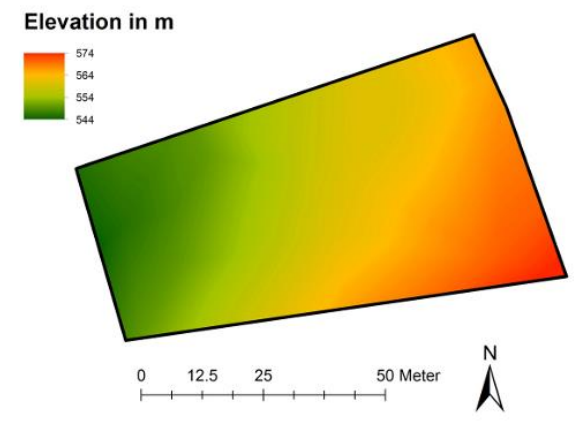

Digitized Cow Paths

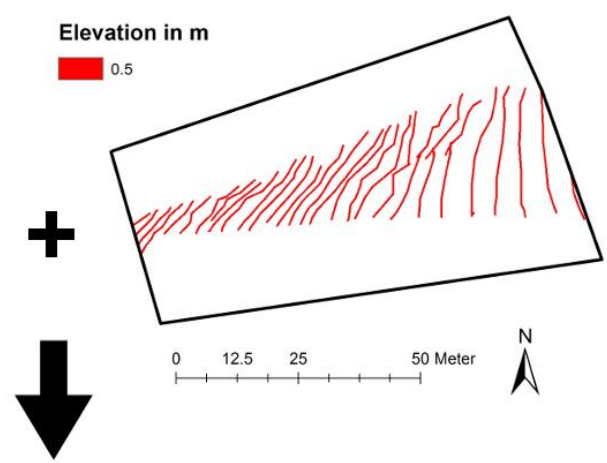

3D Model of DEM with Cow Paths

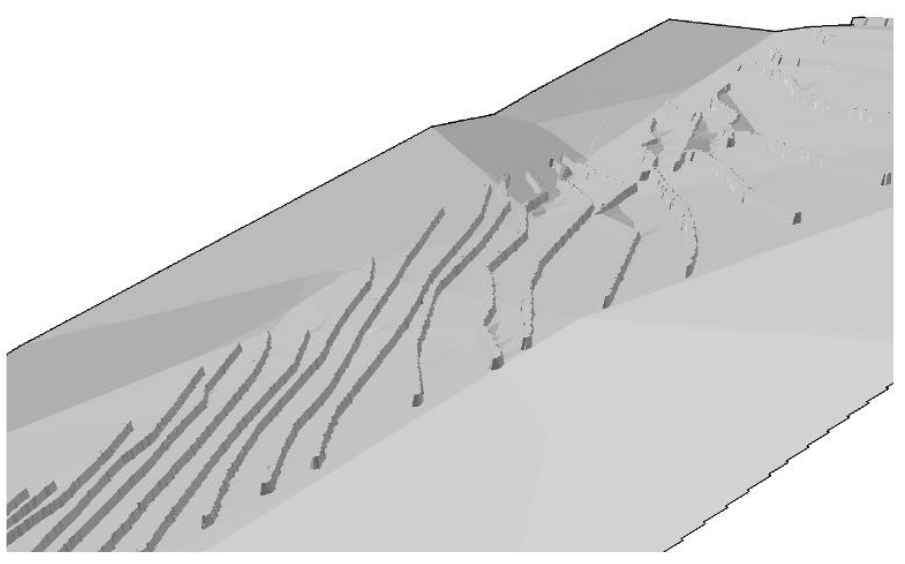

Figure 4. A DEM of a section of an area supporting a well-developed terracette system was merged with digitized trample paths to create a three-dimensional model of a section of a terracette system.

taken for both DEMs and the resulting raster files were exported back into ArcMap in order to create maps of the runoff simulation area. Finally, ArcMap was then used to create two maps of the runoff accumulation pathways in order to show respective runoff patterns across both DEMs.

\subsection{Rainfall simulations}

Eight separate rainfall simulations, each lasting for $30 \mathrm{~min}$, were conducted on 10 and 25 April 2014 on small bounded sections of terracettes. Water was pumped at a pressure of around $0.4 \mathrm{bar}$ ( $\pm 0.1 \mathrm{bar}$ ) to a single-spray system (Spraying Systems Fulljet nozzle, type: 1/4 HH - 14 WSQ) which generated artificial rain with an estimated median drop diameter of around $1.5 \mathrm{~mm}$. The rainfall simulator was supported by a lightweight yet robust aluminium frame, the shape of which can be adjusted to suit localised topographic conditions, and which gave an approximate drop-height of $1.2 \mathrm{~m}$ from the nozzle outlet to the target area (Fig. 5). The configuration and geometry of each selected are varied slightly and reflected the proportion that was occupied by either a runner (i.e. the step) or riser (i.e. near-vertical or sloping component) within each bounded area. The extent of bounded plots ranged from $0.23 \mathrm{~m}^{2}$ (Expt. 8) to $1.10 \mathrm{~m}^{2}$ (Expt. 2). Each plot was delineated using aluminium sheets embedded edge-on into the soil. A runoff collection trough was also embedded flush with the soil surface at the downslope end and was used to channel any runoff into plastic containers. Due to the fact that all terracette runners within selected areas were located on generally planar surfaces, only the average gradient of each section of riser is reported and these ranged from ca. $10 \%$ $\left(5.7^{\circ}\right)$ (Expt. 8) to ca. $75 \%\left(36.5^{\circ}\right)$ (Expt. 4). Rainfall intensity was measured by simultaneously taking an average of three rainfall measurements within the rain-drop zone. Intensity values ranged from an equivalent of $47 \mathrm{~mm} \mathrm{~h}^{-1}$ (Expt. 5) to $110 \mathrm{~mm} \mathrm{~h}^{-1}$ (Expt. 2). Although these intensities are relatively high, if they are expressed as equivalent cumulative rainfall per single event (mm), the obtained values generally fall within the natural range of events reported in the Jura region, albeit within the upper range (Ogermann et al., 


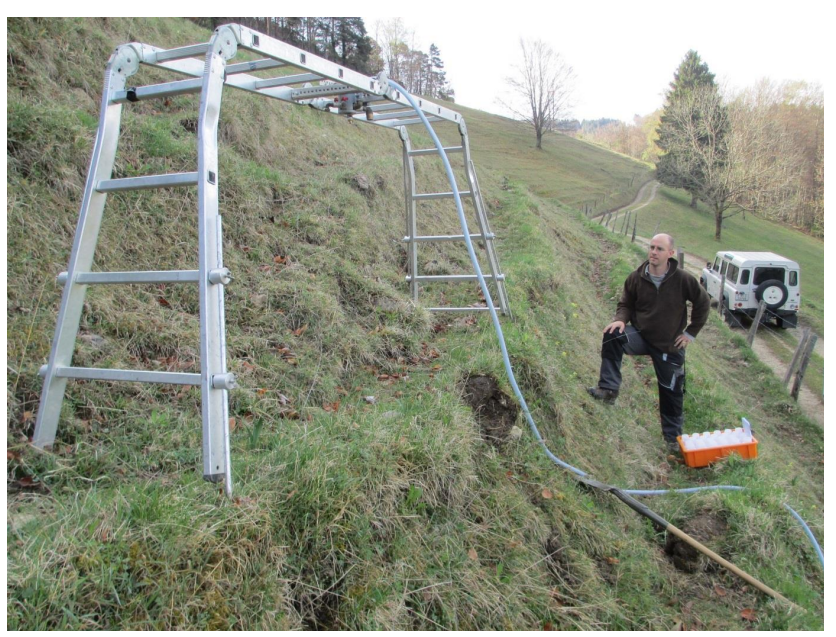

Figure 5. The adjustable aluminium frame supporting the rainfall simulator. Such a configuration allows the simulator to be firmly supported and level, even on challenging terrain such as a welldeveloped terracette system on a steep slope.

2003). In addition, despite the fact that intense rainfall over prolonged periods of time is rare, intensities such as these represented the best chance of generating surface runoff in a relatively short period of time.

Despite selecting the same pump pressure during each rainfall simulation, broader variations in rainfall intensities than originally desired were obtained over the eight simulations. This is attributed to differences in end-of-pipe pressures, presumably brought about by changing height differences between the pump outlet and the rainfall simulator as it was moved further up- or across-slope to different sites. For the purpose of this investigation, we also define runoff as a steady and continuous flow of water leaving the plot outlet. Once runoff was obtained, a soluble coloured tracer (indigo blue) was applied from a pipette onto the upslope edge of the rainfall drop zone in order to provide an indication of the time taken for the tracer to be recovered at the plot outlet. Key data for each of the eight rainfall simulations are listed in Table 1.

\section{Results and discussion}

\subsection{Runoff accumulation DEM}

After following the methodological steps outlined in Sects. 2.2 to 2.4, a DEM of the terracette system was created and is shown in Fig. 6. The approach clearly identifies runoff accumulation paths and the natural trajectory of the slope juxtaposed over approximately $60 \%$ of the area under scrutiny. Why the method only depicts just over half of the visible terracette system is not clear but may be related to poor sensitivity associated with the flow-accumulation algorithm in the IDRISI GIS package. In addition, the method

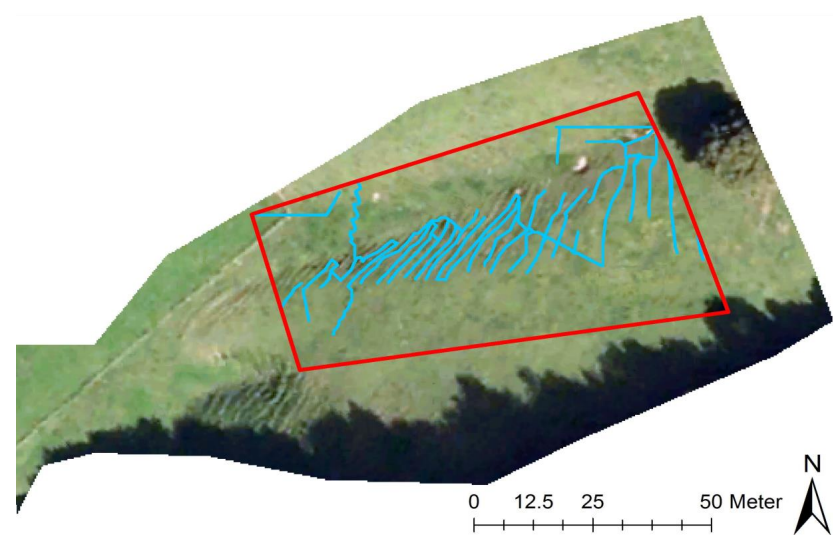

Figure 6. A three-dimensional model shows clearly defined juxtaposed flow-accumulation paths and the natural gradient of the slope. Such a system may have the ability to influence surface runoff.

also led to the creation of a number of diagonally orientated flow paths (Fig. 6). These are believed to be spurious features and probably represent a product of the way in which topographic data are converted to raster data (Hopkinson et al., 2009). A possible way in which this problem will be avoided in future is discussed in Sect. 4. Despite the occurrence of these anomalous features and the fact that only partial coverage of the terracette system was obtained, the resultant output is still believed to provide adequate proof of concept of the role of terracettes and was sufficiently encouraging to continue with the second, physical-based experimental phase of the investigation.

\subsection{Rainfall simulations}

Four key measurements relating to runoff characteristics were recorded during each rainfall event, the results of which are listed in Table 1. The time taken for runoff to commence ranged from 136 (Expt. 4) to $1710 \mathrm{~s}$ (Expt. 5). The time taken for the tracer to be recovered in surface-runoff after application ranged from just 45 (Expt. 1) to $1210 \mathrm{~s}$ (Expt. 5). The amount of time between terminating rainfall and the cessation of runoff ranged from 11 (Expt. 5) to $230 \mathrm{~s}$ (Expt. 6), and finally, runoff coefficients ranged from 0.1 (Expt. 5) to $23.5 \%$ (Expt. 3).

A relatively weak indirect exponential correlation $\left(r^{2}=\right.$ $0.338(33.8 \%)$ ) was obtained for the relationship between average riser gradient and the time taken for continuous runoff to commence. Despite the fact that a stronger result was not obtained for these two variables, the indirect relationship implies that gradient has the ability to exert some control over runoff generation times. No relationship was found between average riser gradient and tracer recovery time after application. Likely reasons for this could be localised variations in the physical and environmental characteristics of each plot. Those main variables under consideration include bulk density, soil pore space, antecedent soil 
Table 1. Key characteristics associated with eight rainfall simulations, performed over 2 separate days in April 2014 on bounded sections of a terracette system.

\begin{tabular}{|c|c|c|c|c|c|c|c|c|}
\hline ID & Date performed & $\begin{array}{r}\text { Av. riser } \\
\text { grad. }(\%)\end{array}$ & $\begin{array}{l}\text { Raindrop } \\
\text { area }\left(\mathrm{m}^{2}\right)\end{array}$ & $\begin{array}{l}\text { Av. rainfall } \\
\text { intensity } \\
\left(\mathrm{mm} \mathrm{h}^{-1}\right)\end{array}$ & $\begin{array}{r}\text { Time to } \\
\text { continuous runoff } \\
\text { commencing }(\mathrm{s})\end{array}$ & $\begin{array}{r}\text { Tracer recovery } \\
\text { time after } \\
\text { application (s) }\end{array}$ & $\begin{array}{r}\text { Time runoff } \\
\text { stopped } \\
\text { after rainfall (s) }\end{array}$ & $\begin{array}{r}\text { Runoff coeff. } \\
(\%)\end{array}$ \\
\hline Simulation 1 & & 50 & 0.99 & 102 & 1155 & 45 & 50 & 0.9 \\
\hline Simulation 2 & $10 \triangle$ mril 2014 & 40 & 1.10 & 110 & 180 & 70 & 168 & 10.5 \\
\hline Simulation 3 & 10 April 2014 & 39 & 0.54 & 98 & 292 & 80 & 90 & 23.5 \\
\hline Simulation 4 & & 75 & 1.08 & 87 & 136 & 200 & 180 & 14.0 \\
\hline Simulation 5 & & 35.3 & 0.64 & 47 & 1710 & 1210 & 11 & 0.1 \\
\hline Simulation 6 & 25 Anril 2014 & 42.1 & 0.81 & 92 & 1440 & 1170 & 230 & 2.0 \\
\hline Simulation 7 & 2Ј Арा11 2014 & 11.7 & 0.35 & 67 & 1181 & 360 & 65 & 4.9 \\
\hline Simulation 8 & & 10 & 0.23 & 99 & 1210 & 120 & 15 & 11.2 \\
\hline
\end{tabular}

moisture content and concomitant soil matric potential. It is also acknowledged that differences in factors between sites, such as the density and length of vegetation cover and/or the exposure of fragmented stones on or partially embedded into the soil surface, can also exert notable controls over runoff generation (Ries et al., 2013).

\subsection{Runoff coefficients}

Runoff coefficients for the eight plots ranged from just 0.1 (Expt. 5) to $23.5 \%$ (Expt. 3). The wide variation is believed to reflect variations in the physical characteristics of the soil, but in this instance it principally reflects variations in infiltration rates. Reasons why infiltration is considered to represent a major control on runoff generation relate to variations in the bulk density of the surface soil. Five in situ bulk density measurements were taken from the upper soil profile $(0-5 \mathrm{~cm}$ deep) next to four of the plots before rainfall was applied. After the samples were oven dried, linear regression was undertaken for the variables, bulk density and runoff coefficients. This returned a very strong direct $r^{2}$ correlation of 0.992 (99.2\%), which is shown in Fig. 7. Consequently, an assumption is made that where bulk densities are high, infiltration rates are presumably low and vice versa. Higher runoff coefficients therefore imply that certain sections of runners within this particular terracette system have experienced some degree of compaction and this would appear to represent one of the major factors controlling runoff generation. The reason for this is cautiously attributed to the trampling of certain sections of runners within the terracette system, presumably, in this instance, by livestock. By contrast, where runoff coefficients are low, higher infiltration rates are taken as an indication of relatively uncompacted soil surface conditions. This would suggest that opportunity for both runoff generation and its downslope conveyance is limited during everything but the most intense rainfall event. Indeed, if an arbitrary $10 \%$ runoff coefficient is taken as a "cut-off" threshold, then $50 \%$ of plots that were subjected to simulated rainfall (i.e. four) would appear to be capable of generating runoff (i.e. plots 2, 3, 4 and 8). In generating

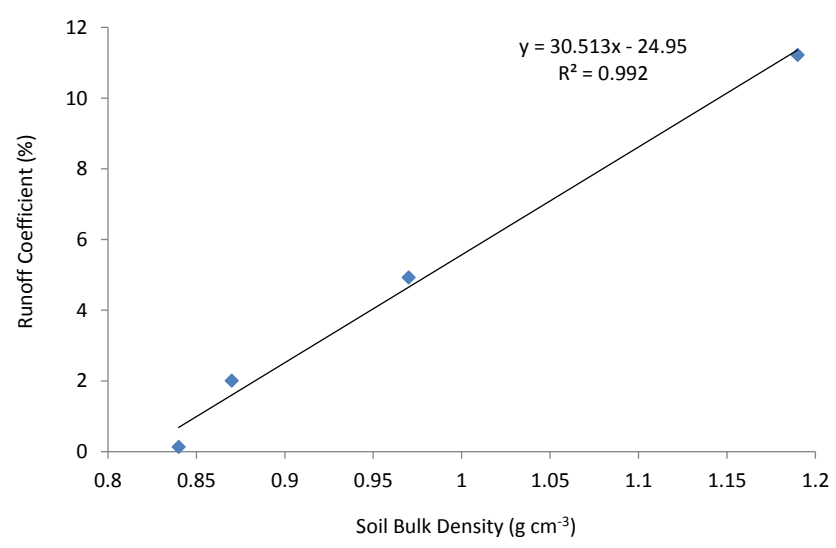

Figure 7. A strong direct correlation was obtained for the relationship between soil bulk density and runoff coefficient at the four plots that were tested.

runoff, not only could these sites realistically act as sediment sources, but the high connectivity would render them potentially capable of conveying runoff downslope. In retrospect, however, higher infiltration rates at the remaining plots (i.e. 1, 5, 6 and 7) means that these areas are largely incapable of conveying runoff, even during the most intense rainfall event, and are hence disconnected. Logically, such areas could feasibly act as depositional sites where substances, mobilised and transported from elsewhere upslope, enter into temporary storage.

Attempts were made to further test the compaction hypothesis, by correlating the runoff coefficient values against times taken for continuous runoff to commence. A considerably weaker $r^{2}$ value of $0.615(61.5 \%)$ suggests that numerous other factors aside from compaction and reduced infiltration rates appear to exert a considerable control on runoff generation (Ries et al., 2013). Those under consideration could, again, be due to localised variations in vegetation and soil surface characteristics but in this instance are thought to relate to antecedent soil moisture; the likely implications of this are discussed in more detail in the following subsection. 
Table 2. Mean \% volumetric soil moisture content was calculated for each pair of runners and risers within each plot before and after rainfall application in order to quantify the net change in moisture content.

\begin{tabular}{lrrrrrrrr}
\hline & \multicolumn{6}{c}{ Net volumetric change (\%) moisture content, before and after experiments } \\
\cline { 2 - 8 } & Sim. 1 & Sim. 2 & Sim. 3 & Sim. 4 & Sim. 5 & Sim. 6 & Sim. 7 & Sim. 8 \\
\hline Runner (step) & no data & -0.04 & -0.02 & -4.38 & 5.33 & 8.11 & 7.65 & 8.78 \\
Riser (vertical) & no data & 5.30 & 2.70 & 2.10 & 1.61 & 6.78 & 3.30 & 1.22 \\
\% Runoff coefficients & 0.85 & 10.48 & 23.51 & 14.01 & 0.13 & 2.01 & 4.93 & 11.22 \\
\hline
\end{tabular}

\subsection{Localised variations in soil conditions}

Additional in situ bulk density measurements were obtained from a number of terracette paths, away from those areas subjected to simulated rainfall, and compared with measurements taken from a nearby, relatively flat meadow situated at the foot of the slope on which the terracette system is located, which also provides grazing for cattle. The average value of $0.82 \mathrm{~g} \mathrm{~cm}^{-3}$ for meadow samples $(n=6)$ contrasts with the $1.00 \mathrm{~g} \mathrm{~cm}^{-3}$ recorded from the runners $(n=25)$. The result strongly suggests that the soil surface, certainly of those runners that were measured, has probably experienced considerably more compaction than soil surface within the meadow environment. This conclusion is supported by in situ soilpore data taken from those same terracette and meadow locations as previously mentioned. Water loss from $100 \mathrm{~cm}^{3} \mathrm{sam}-$ ples of in situ soil taken from both sets of locations $(n=12)$ were recorded over a 2-week period. Water-loss data were recorded; firstly, solely under the influence of gravity and then air pressures were gradually increased to the equivalent of 200, 400 and finally 800 mbar. Differences in the two data sets were then determined statistically by subjecting them to a non-parametric Friedman test, performed at the $95 \%$ confidence level, to determine whether differences were significant. The statistical output indicated that water loss from soil samples taken from the surface of runners on the terracette system was significantly greater $(P<0.05)$ than water loss from soil taken from the nearby meadow. Likely reasons for this are believed to relate to reduced pore space and the fact that water storage capacity is significantly less than soil from meadow areas. This is tentatively attributed to the effect of compaction and this, again, is presumably due to excessive trampling of the soil surface by livestock.

Precipitation, air temperature and soil matric potential data were also recorded from a climate station located near to the experimental area prior to undertaking rainfall simulations. Taking an arbitrary yet suitably long 5-day period prior to when each set of rainfall simulations were conducted (i.e. from 5 to 10 April 2014 and from 20 to 25 April 2014), cumulative precipitation measured $14.0 \mathrm{~mm}$ over the first of those periods and $6.4 \mathrm{~mm}$ over the second 5-day period. However, average soil matric potential values for those corresponding periods measured -19 and $-169 \mathrm{kPa}$ respectively. The first value equates to very wet, almost saturated, condi- tions and the second to very dry conditions (Shukla, 2014). Although more than double the amount of precipitation fell over the first 5-day period prior to 10 April, average soil matric potential was approximately 9 times more negative over the second 5-day period prior to 25 April. It is difficult to attribute this large difference to precipitation alone, but contrasting air temperatures, presumably leading to variable evapotranspiration rates, may provide at least some explanation for the drier conditions leading up to, and including, the second experimental day. Average air temperature over the 5 days prior to 10 April when Simulations 1-4 were performed was $10.4^{\circ} \mathrm{C}$ but averaged $20.7^{\circ} \mathrm{C}$ over the 5 days prior to 25 April when Simulations 5-8 were performed. The marked difference in soil matric potential over the two periods is thus thought to reflect differences in antecedent soil moisture conditions. This may explain why the average time to continuous runoff was just $441 \mathrm{~s}$ for Simulations 1-4 but was $1358 \mathrm{~s}$ for Simulations 5-8. Despite making no changes to the way in which sites were selected over the 2 days, in general, $75 \%$ of plots tested on the first day recorded relatively high runoff coefficients (i.e. $>10 \%$ ). With an ability to convey surface runoff, they therefore expressed some evidence of connectivity. By contrast, however, $75 \%$ of plots tested on the second day recorded relatively low runoff coefficients (i.e. $<10 \%$ ). Higher infiltration and an apparent inability to generate and convey surface runoff means that these areas could act as depositional sites where runoff-associated substances may be temporarily stored between erosion events.

\subsection{Net changes in in situ volumetric soil moisture content}

In situ volumetric soil moisture conditions were determined using a TRIME-FM (version P2) in situ volumetric soil moisture probe (IMKO $\mathrm{GmbH}$ ). Measurements were taken from pairs of runner and riser components within each plot before simulated rainfall was applied, and then approximately $30 \mathrm{~s}$ after rainfall was terminated. Moisture values from each geomorphic component were averaged for each plot, and postrainfall values were subtracted from pre-rainfall values in order to provide an indication of the net change in soil moisture content. The results of this procedure, which are listed in Table 2, combined with runoff coefficient data listed in Table 1, tend to agree with explanations made in previous subsections 
inasmuch as some runner and riser systems appear to generate surface runoff, whereas others do not.

No moisture content data are available for Simulation 1; however, for Simulations 2-4 a net loss in soil moisture content was recorded for all three runners, with values ranging from -0.02 to $-4.38 \%$. Although these values could be within the error uncertainty associated with the moisture probe, this overall result is generally interpreted as an indication of the reduced infiltration capacity of runners at locations where Simulations 1-4 were conducted. This, again, is tentatively attributed to compaction of the soil surface, presumably by trampling livestock. Assuming sufficient natural rainfall fell to initiate such conditions, it is possible that this particular group of runners could shed surface water and hence would be more likely to generate surface runoff, possibly leading to erosion in some instances.

For the risers at sites on which Simulations 2-4 were conducted, all recorded a net gain in moisture content which ranged from 1.61 to $5.30 \%$. Despite the acute gradients associated with these three risers (39-75\%, Table 1), and the fact that the highest runoff coefficients were also recorded at these sites (Table 1), the net positive change in moisture content infers that steep-sloping risers such as these are still able to absorb some water during an intense and relatively prolonged rainfall event. Although these three sites recorded among the highest runoff coefficients of the eight simulations, the values are still relatively low; this suggests that runoff generation, the contribution of overland flow from these steep-sloping risers and their ability to convey runoff downslope would remain relatively small. In contrast, pairs of runners and risers from Simulations 5 to 8 all recorded net positive changes in soil moisture content. For the runners, increases ranged from 5.33 to $8.78 \%$. These values are particularly high and considerably higher than comparable values recorded by each corresponding riser. Considering the explanation given above, it is logical to assume, therefore, that the soil surface associated with this particular group of runners is probably less compacted and they are, henceforth, less likely to generate and convey surface runoff. This overall finding accords with the magnitude of runoff coefficients recorded from Simulations 5 to 8 , which, as previously noted at $0.1-$ $11.2 \%$ (Table 1), are considerably lower than the runoff coefficients generated during Simulations 2-4. It is possible, however, that lower compaction levels similar to those areas identified during Simulations 5-8 may exist along certain sections of runners within this particular terracette system. Based on this premise, it is entirely feasible that such areas would be unable to convey runoff downslope and as such could actually act as net depositional environments, thereby providing increased opportunity for runoff-eroded material to enter into temporary storage. Whether this scenario is prevalent and representative of other terracette systems elsewhere remains unknown at present, but issues such as this will undoubtedly need to be determined during future work.

\section{Future work}

Using the results from this investigation as a preliminary foundation on which to further elucidate the influence of terracettes on the surface hydrology of steeply sloping environments, a package of future work and/or refinements to existing methods is planned for the future.

For the GIS component of the investigation, the main goal is to increase the sensitivity of any DEMs that are used in the future. Consequently, this will probably involve using terrestrial laser scanning to create high-resolution bespoke DEMs over relevant spatial scales. For the experimental work a number of key refinements will be implemented to the existing methods. These will likely include

1. Siting plots so that the proportion of the area occupied by the runner and riser are similar for all plots;

2. Selecting test areas that express generally similar risergradients;

3. Delineating each plot so that areas and geometries are similar;

4. Taking multiple in situ bulk density measurements close to all plots prior to rainfall application;

5. Generating rainfall with generally similar intensities;

6. Closer and more intense monitoring of soil hydrological properties and how these vary from site to site.

In addition to the above, it is envisaged that, in future, the riser (i.e. the area where the majority of runoff is thought to be generated) will be temporarily separated from the runner in each plot during the first half of the rainfall event (i.e. for the first $15 \mathrm{~min}$ ) in order to prevent runoff from entering the downslope, or runner, section of the plot. During this initial phase, time to runoff-generation, cumulative volume of runoff generated and runoff coefficient will be measured. Without stopping the rainfall, the boundary separating the two components will then be removed in order to allow connectivity between the two geomorphic components. The same variables as above will then be measured again. Although identifying suitable sections of terracettes that meet these more stringent criteria will inevitably make the site selection process more difficult and time consuming, the resultant data should, firstly, provide an indication of the volume of runoff that each geomorphic component of a terracette system (i.e. the runner and the riser) contributes to an overall surface runoff budget. Secondly, these changes will unify the series of experiments and thus serve to make plot-derived data more comparable.

\section{Conclusions}

The investigation combined a number of complimentary analytical approaches for the purpose of testing the hypothe- 
sis that terracettes have the ability to influence surface hydrology in subalpine and steeply sloping terrain. Within the constraints and limitations of the methodological and experimental techniques that were employed, a number of very preliminary conclusions can be drawn from this two-phase investigation. Firstly, the GIS-based approach provided adequate proof of concept that terracettes can indeed have an influence on the surface hydrology on steeply sloping environments. Whether individual terracette pathways act in an interconnected way to form a complete runoff conveyance system that guides, or even facilitates, the downslope movement of surface runoff is unknown. Some data from the experimental phase support this possibility by demonstrating that runoff could be generated from four areas within the terracette system. This suggests that those areas have probably experienced some degree of compaction, which is tentatively attributed to the effect of trampling, presumably by livestock. Importantly, however, in readily generating runoff, those areas may have the ability to convey surface runoff and associated material downslope. By contrast, and despite applying equally high-intensity rainfall, very little runoff was generated from four areas within the same terracette system that was investigated. Whilst this initially suggests that those areas are presumably relatively uncompacted, these findings also infer that such areas could probably not convey surface runoff downslope. As such, they represent a natural hiatus, or disconnection, in the downslope conveyance process that is commonly found in the majority of hillslope environments. Based on this surprising and almost serendipitous finding, we cautiously suggest that uncompacted areas within a terracette system may actually act as depositional sites, with the possibility of retaining, or even temporarily storing, runoffassociated material, at least until the next runoff event. Based on these interesting, yet somewhat contradictory and almost serendipitous results, further work is required to determine whether the findings reported here are representative of this and other terracette systems elsewhere.

Acknowledgements. We thank Guy Broquet from the village of Movelier, Canton Jura in northwest Switzerland, for granting ongoing access to the study site.

Edited by: M. Hoelzle

Reviewed by: two anonymous referees

\section{References}

Anderson, R. S. and Anderson, S. P.: Geomorphology: The Mechanics and Chemistry of Landscapes, Cambridge University Press, New York, 2011.

Anderson, E. W. and Cox, N. J.: A comparison of different instruments for measuring soil creep, Catena, 5, 81-93, 1978.

Auzet, A.-V. and Ambrose, B.: Soil creep dynamics, soil moisture and temperature conditions on a forested slope in the granitic
Vosges Mountains, France, Earth Surf. Proc. Land., 21, 531-542, 1996.

Bell, M.: Valley sediments as evidence of prehistoric land use: A study based on dry valleys of southeast England, Unpublished $\mathrm{PhD}$ Thesis, Institute of Archaeology, University of London, UK, 1981.

Bielecki, A. E. and Mueller, K. J.: Origin of terraced hillslopes on active folds in the southern San Joaquin Valley, California, Geomorphology, 42, 131-152, 2002.

Buckhouse, J. C. and Krueger, W. C.: What caused those terracettes, Rangelands, 3, 72-73, 1981.

Carson, M. A. and Kirkby, M. J.: Hillslope Form and Process, Cambridge Geographical Studies No. 3, Cambridge University Press, Cambridge, UK, 1972.

Greenwood, P. and Kuhn, N. J.: Does the invasive plant, Impatiens glandulifera, promote soil erosion along the riparian zone? An investigation on a small watercourse in northwest Switzerland, J. Soil. Sed., 14, 637-650, 2014.

Heimsath, A., Chappell, J., Spooner, N. A., and Questiaux, D. G.: Creeping soil, Geology, 30, 111-114, 2002.

Henck, A., Taylor, J., Lu, H, Li, Y., Yang, Q., Grub, B., Breslow, S. J., Robbins, A., Elliott, A., Hinckley, T., Combs, J., Urgenson, L., Widder, S., Hu, X., Ma, Z., Yuan, Y., Jian, D., Liao, X., and Tang, Y.: Anthropogenic hillslope terraces and swidden agriculture in Jiuzhaigou National Park, northern Sichuan, China, Quaternary Res., 73, 201-207, 2010.

Hoffmann, U., Hoffmann, T., Jurasinski, G., Glatzel, S., and Kuhn, N. J.: Assessing the spatial variability of soil organic carbon stocks in an alpine setting (Grindelwald, Swiss Alps), Geoderma, 232-234, 270-283, 2014.

Hopkinson, C., Hayashi, M., and Peddle, D.: Comparing alpine watershed attributes from LiDAR, photogrammetric, and contourbased digital elevation models, Hydrol. Process., 23, 451-463, 2009.

Konz, N., Prasuhn, V., and Alewell, C.: On the measurement of alpine soil erosion, Catena, 91, 63-71, 2012.

Kuhn, N. J. and Zhu, H.: GIS-based modeling of runoff source areas and pathways, Geogr. Helv., 63, 48-57, doi:10.5194/gh-63-482008, 2008.

Ledermann, T., Herweg, K., Liniger, H., Schneider, F., Hurni, H., and Prasuhn, V.: Erosion damage mapping: assessing current erosion damage in Switzerland, Adv. GeoEcol., 39, 263-283, 2008.

Michna, P., Eugster, W., Hiller, R. V., Zeeman, M. J., and Wanner, H.: Topoclimatological case-study of Alpine pastures near the Albula Pass in the eastern Swiss Alps, Geogr. Helv., 68, 249263, doi:10.5194/gh-68-249-2013, 2013.

Ødum, H.: Om "Faarestiernes" Natur ("On the nature of the socalled sheep tracks”), Dansk. Geol. Fören Medd., 6, 1-29, 1922.

Ogermann, P., Meier, S., and Leser, H.: Ergebnisse langjähriger Bodenerosionskartierungen im Schweizer Tafeljura (Results of long-term soil erosion mapping in the Swiss Jura Plateau), Landnutzung und Landentwicklung, 44, 151-160, 2003.

Prasuhn, V.: Bodenerosionsformen und -prozesse auf tonreichen Böden des Basler Tafeljura (Raum Anwil) und ihre Auswirkungen auf den Landschaftshaushalt, Physiogeographica, Basler Beiträge z. Physiogeographie Band. 16, Basel, Switzerland, 1991.

Prasuhn, V.: Soil erosion in the Swiss midlands: Results of a 10-year field survey, Geomorphology, 126, 32-41, 2011. 
Rahm, D. A.: The terracette problem, Northwest Sci., 36, 65-80, 1962.

Ries, J. B., Iserloh, T., Seeger, M., and Gabriels, D.: Rainfall simulations - constraints and challenges for a future use in soil erosion research, Zeitshrift für Geomorphologie, 57, 1-10, 2013.

Rodwell, J. (Ed.).: British Plant Communities, Volume 3 Grasslands and montane communities, Cambridge University Press, Cambridge, 1998.

Rorison, I. H.: Soils, mineral nutrition and climate. In: Calcareous Grassland Ecology and Management, in: Proceedings of a Joint British Ecological Society / Nature Conservancy Council Symposium, edited by: Hillier, S. H., Walton, D. W. H., and Wells, D. A., Bluntisham Books, UK, 21-28, 1990.
Shukla, M. K.: Soil Physics: An Introduction, CRC Press, Taylor Francis Group, London, UK, 2014.

Vincent, P. and Clarke, V.: Terracette morphology and soil properties: a note on a canonical correlation study, Earth Surf. Proc. Land., 5, 291-295, 1980.

Waugh, D.: Geography: An Integrated Approach (2nd edn.), Thomas Nelson \& Sons, Surrey, UK, 1995.

White, R. E.: Principles and Practice of Soil Science: The Soil as a Natural Resource (3rd edn.), Blackwell Science Publishers, London, UK, 2000. 